\title{
Cooperate Social Responsibility in Recent Thar Crisis: A Case Study of FFC Fertilizer MirPur Mathelo \\ Dr.Ghul Murtaza Maitlo
}

Dean Faculty of Commerce \& Business Administration

Shah Abdul latif University Khairpur

\section{Zahid Hussain Kazi}

Assistant Professor

IBA-University of Sindh-Jamshoro

\section{Dr.Ambreen Khaskheley}

\author{
Assistant Professor-Deptt:Economics \\ University of Sindh-Jamshoro
}

Faiz M.Shaikh

\section{Assistant Professor-SZABAC-Dokri-Larkana-Sindh-Pakistan faizanmy2000@hotmail.com}

\begin{abstract}
The current research investigates the Cooperate Social Responsibility and Sustainable Development: A Case Study of FFC Fertilizer MirPur MatheloData were collected from300 stake holders and 400 local people from Mirpur Mathelo and their vicinity. Structural questionnaire were developed for the reliability and validity of the data. It was revealed that The unfolding drought in Tharparkar has created a humanitarian crisis for the approximate 1.5 million inhabitants of the district. An all-out relief effort is underway to assist the remote desert communities. The recent draught in Thar where thousands of child were died with out feed. FFC not only provide them feed but also help them by providing health facilities to them.
\end{abstract}

Keywords: Social responsibility, Private enterprise, Sustainable development

\section{Council for Innovative Research}

Peer Review Research Publishing System

Journal: International Journal Of Management \& Information Technology

Vol. 10, No 5

editorsijmit@gmail.com

www.ijmit.com 


\section{Definition and Features of Corporate Social Responsibility}

According to all the above definitions, it is clear that in addition to their traditional economic roles, enterprises are also expected to $p$ their social roles as "agents" in order to guarantee the sound operation of market economy. As the agents of social resources, enterpris should serve not only their shareholders, consumers and employees but also the whole society. Therefore, its general connotation refer enterprises' responsibility in many ways to guarantee social welfare, stability and development, which includes (1) enterpris responsibility for their owners by guaranteeing profit and development, (2) enterprises' responsibility for their consumers by providing ge and cheap goods, (3) enterprises' responsibility for creditors by paying off debt on time, (4) enterprises' responsibility for employe including good salary, favorable working conditions, opportunities for training and promotion, (5) enterprises' responsibility for governm and community by paying taxes, profits, fees legally and providing equal employment opportunities in order to improve social and polit stability and economic prosperity, (6) enterprises' responsibility for social environment mainly by protecting and treating environmen order to provide a better living place for residents.

FFC participated as a major shareholder in a new DAP/Urea manufacturing complex with participation of major international/national institutions. The new company Fauji Fertilizer Bin Qasim Limited (formerly FFC-Jordan Fertilizer Company Limited) commenced commercial production with effect from January 01,2000 . The facility is designed with an annual capacity of 551,000 metric tons of urea and 445,500 metric tons of DAP, revamped to 670,000 metric tons of DAP.

With a vision to acquire self - sufficiency in fertilizer production in the country, FFC was incorporated in 1978 as a private limited company. This was a joint venture between Fauji Foundation and Haldor Topsoe A/S.

The initial share capital of the company was 813.9 Million Rupees. The present share capital of the company stands above Rs. 8.48 Billion. Additionally, FFC has more than Rs. 8.3 Billion as long term investments which include stakes in the subsidiaries FFBL, FFCEL and associate FCCL.

\section{Literature Review}

Corporate Social Responsibility is the way in which a company manages and improves its social and environmental impact to generate value for both its shareholders and its stakeholders by innovating its strategy, organization and operations ;CSR Europe (2003). CSR can be thus be simply defined as the additional commitment by businesses to improve the social and economic status of various stakeholders involved while complying with all legal and economic requirements, Warhust, A. (2001). Reinhardt et al (2008) and Bénabou \& Tirole (2009 adopted a simple standard definition of CSR originally Offered by Elhauge (2005) that is: sacrificing profits in the social interest. For there, to be a sacrifice, the firm must go beyond its legal and contractual obligations, on a voluntary basis. According to Hopkins (2004) and Abd Rahim, et al (2011) CSR can be defined as treating the stakeholders of the firm ethically or in a responsible manner (Hopkins, Michael (2004). Koestoer (2007) offered definition of CSR in the following words: Ways of companies in addressing various social issues in their operating areas, individually or collectively, are known as Corporate Social Responsibility (CSR). Sriramesh et al (2007 and Ismail (2011) reported that Bowen (1953) identified as the pioneer in providing the modern literature on CSR, offered one of the earliest definitions seeing CSR as the "obligations of businessmen to pursue those policies, to make those decisions, or to follow those lines of action which are desirable in terms of the objectives and values of our society". Kim, (2011) asserted by quoting many studies ((Friedman, 1970; Jensen, 2000; Davis, 1967; Donaldson \& Dunfee, 1999) that since Bowen (1953) defined CSR as a method employed by corporations to pursue policies, decisions, and actions for the social purpose and value. Mahlouji and Anaraki (2009) referred a definition by David Waldman et al. (2006) who defined CSR as actions on the part of the firm that appear to advance, or acquiesce in the promotion of some social good, beyond the immediate interests of the firm and its shareholders, which is required by law. Such actions may result in a company embodying socially responsible attributes in their products. Corporations should transition from a state of mere compliance to a mode of engagement, from harm minimization to value creation (Luetkenhorst, W.: 2004).

Data Collection Methodology

Data were collected from300 stake holders and 400 local people from Mirpur Mathelo and their vicinity. Structural questionnaire were developed for the reliability and validity of the data. Data were analyzed by using SPSS-21.

\section{Results}

The unfolding drought in Tharparkar has created a humanitarian crisis for the approximate 1.5 million inhabitants of the district. An all-out relief effort is underway to assist the remote desert communities on timely basis. Being the largest fertilizer manufacturer of Pakistan, FFC has made prompt response to the crisis through its CSR program. Disaster relief and rehabilitation remains centric to FFC CSR strategy in addition to Education, Healthcare, Poverty Alleviation, Environmental Protection and Community Uplift. FFC relief convoy with 22 ton dry ration reached the remote district on 12th March 2014 from its regional office in Karachi. The comprehensive relief package from FFC included basic necessity packs (BNP) for 1100 families. The BNP comprised of dry ration including Sugar, flour (Wheat), Dry Milk, Cooking Oil, Energy Drinks, Mineral Water and Tea. Also, the relief supply included community medicines to support the remote medical units established in the far flung areas of the district.FFC, being the pioneer of sustainable and responsible business practices initiated its 1st CSR program in 1982 (The Agri Service) which is geared to achieve food security for the nation. The program includes capacity building and technical assistance of the farmers across Pakistan to held them increase the yield of their crop, which in return guarantees provision of timely and quality crop to the 180 million Pakistanis. FFC will continue to play its role in Thar as well in the coming months whereas comprehensive intervention for last year earthquake affectees of Baluchistan is also in progress. For Fauji Fertilizer Company Limited, social responsibility 
means facilitating communities and empowering its people. Sustainability shall always remain quintessential for the performance of CSR. Historically, FFC has always been socially a responsible corporate entity. The Company started its CSR per se as early as in 1982 by introducing Agri-Services thus helping in poverty alleviation of common farmer and assisting them in sustained empowerment. Gradually FFC started interventions in most of the defined sectors and has developed a history of about 30 years of contributions to the society. FFC, further plans to bring sustainability in its interventions and desires to achieve international standards by aligning CSR with our business objectives. FFC is also committed to improve quality and quantum of its interventions by maximizing on the available resources.

Since FFC has become member of covenants like UNGC, the CSR has to be aligned with international guidelines. It is necessary to standardize the interventions and monitor the quality of interventions at a central level. We need to stay committed to its principles. Keeping the vision of responsible corporate entity in mind, FFC has moved in this direction. FFC has made quality as its core value when it comes to CSR intervention at any level, and in future this will remain as the prime objective.

FFC has also recently constituted a CSR Committee for a meaningful progress in social responsibility.

\section{Current CSR Interventions}

As most of the sustainability conscious organizations around the world do, FFC is playing its part actively in this direction. Being the brand leader in fertilizer sector with the biggest market share and counted among one of the leading corporate entity in Pakistan, FFC understands its obligation in nation building and well being of deprived communities around the plant sites. Under the charter of FFC CSR interventions, following sectors have been made part of the program

$\begin{array}{ll}- & \text { Education } \\ - & \text { Health Care } \\ - & \text { Environment } \\ - & \text { Soverty Alleviation } \\ - & \text { Annual Fun Fares }\end{array}$

Conclusion:The recent crisis of Thar FFC Mirpur Mathelo play a vital role in Disaster relief and rehabilitation remains centric to FFC CSR strategy in addition to Education, Healthcare, Poverty Alleviation, Environmental Protection and Community Uplift. FFC relief convoy with 22 ton dry ration reached the remote district like Thar. The BNP comprised of dry ration including Sugar, flour (Wheat), Dry Milk, Cooking Oil, Energy Drinks, Mineral Water and Tea. Also, the relief supply included community medicines to support the remote medical units established in the far flung areas of the district.

\section{References}

1. Baker, M. (2003) Corporate Social Responsibility - What does it mean?, available at http://www.mallenbaker.net/csr/CSRfiles/definition.html (accessed on December 27, 2003).

2. Bowen, H.R. (1953) Social Responsibilities of the Businessman, New York: Harper and Row.

3. BORZA Mioara (2011) "Some Considerations Regarding the Corporate Social Responsibility Models in Romania”, International Journal of Business and Management Studies Vol. 3, No 2, 2011, pp. 191-200).

4. Bryan W. Husted and José de Jesus Salazar, Taking Friedman Seriously: Maximizing Profits and Social Performance, Journal of Management Studies, January 2006.

5. Bénabou, Roland and Tirole, Jean (2009) "Individual and Corporate Social Responsibility" WP, 09-109, Research Group: Behavioral and Experimental Economics November 11, 2009, Toulouse School of Economics.

6. BORZA Mioara (2011) "Some Considerations Regarding the Corporate Social Responsibility Models in Romania", International Journal of Business and Management Studies Vol. 3, No 2, 2011, pp. 191-200).

7. Business for Social Responsibility: 2001, Introduction to Corporate Social Responsibility. [Online] available: http://www.bsr.org/bsrresources/WhitePapers Issue- Area.cfm.

8. CSR Europe (2003) What is Corporate Social Responsibility?, Available at http://www.csreurope. org/about us/FAQ/\#csr (accessed on December 27, 2003).

9. Carroll, A.B. (1999) 'Corporate social responsibility', Business and Society, Vol. 38, Iss. No. 3, pp.268-295.

10. Carroll, A.B. (1991). The pyramid of corporate social responsibility: toward the moral management of organizational stakeholders. Business Horizons, July-August, pp. 39-48.

11. Clarkson, M. B. E.: 1998, A Stakeholder Framework for Analyzing and Evaluating Corporate Social Performance, in M. B. E. Clarkson (ed.), The Corporation and its Stakeholders: Classic and Contemporary Readings. (University of Toronto Press, Toronto) 243-273.

12. Clarkson, M.: 1995, A Stakeholder Framework For Analyzing and Evaluating Corporate Social Responsibility , The Academy of Management Review 20(1), 92- 118. ; Waddock, S., C. Bodwell and S. Graves: 2002, Responsibility: The New Business Imperative, The Academy of Management Executive 16(2), 132-147.)

13. Carroll, A. B.: 1999, Corporate Social Responsibility: Evolution of a Definitional Construct, Business \& Society 38(3), 268-295.), it does not go as far as in the context of SD. 
14. Carroll, A.B. (1979) 'A three-dimensional conceptual model of corporate performance', Academy of Management Review, Vol. 4, No. 4, pp.497-505.

15. Davis, K. (1973) 'The case for and against business assumption of social responsibilities', Academy of Management Journal, Vol. 16, Iss. No. 2, pp.312-322.

16. Davis, K. (1973). The case for and against business assumption of social responsibilities. Academy of Management Journal, June, pp. 312-322

17. Davis, K. (1960). Can business afford to ignore social responsibilities? California Management Review, 2, pp. 70-76.

18. Dawkins, J. and S. Lewis: 2003, CSR in Stakeholder Expectations and their Implication for Company Strategy, Journal of Business Ethics 44(2-3), 185-193. ISO Advisory Group on Social Responsibility: 2004, 'Working Report on Social Responsibility', www. iso.org/iso/en/info/Conferences/SRConferences/pdf Working\%20Report\%20SR(Apr30).pdf.

19. Epstein, E. M.: 2002, "Religion and Business - The Critical Role of Religious Traditions in Management Education", Journal of Business Ethics, Volume 38, 91-96.

20. European Commission.(2010).Corporate Social Responsibilty(CSR). Retrieved from http://ec.europa.eu/enterprise/policies/sustainable-business/corporate social responsibility/Index_en.htm.

21. European Commission: 2002, 'Communication from the Commission concerning Corporate Social Responsibility: A Business Contribution to Sustainable Development', http://europa.eu.int/comm/employment_ social/socdial/csr/csr2002_en.pdf).

22. European Commission: 2001, Promoting a European Framework for Corporate Social Responsibility. Green Paper. (Office for Official Publications of the European Communities, Luxembourg)http://europe. eu.int/comm/employment_social/soc-dial/csr/ csr2002_en.pdf., sub-heading of the communication; see also ISO Advisory Group on Social Responsibility: 2004, 'Working Report on Social Responsibility', www. iso.org/iso/en/info/Conferences/SRConferences/pdf /Working\%20Report\%20SR(Apr30).pdf. , closely intertwined with the concept of SRM.

23. Frederick, W.C. (1960). The growing concern over social responsibility. California Management Review, 2, pp. 54-61.

24. Friedman, M. (1962). The social responsibility of business is to increase its profits. New York Times, September, 126.

25. Freeman, J.: 1999, Stakeholder Influence Strategies, Academy of Management Review 24(2), 191-205. Figge, F. and S. Schaltegger: 2000, 'What is 'Stakeholder Value? Developing a catchphrase into a Benchmarking Tool', http://www.sustainablevalue.com/Stakeholder $\quad \% 20$ Value\%20\%20Frank\%20Figge\%20and\%20Stefan\% 20Schaltegger\%20(read\%20only).pdf. ;).

26. Gambling, T., and Karim, R.: 1991, Business and Accounting Ethics in Islam, Mansell: London, p33.

27. Hayek, F.A. (1969). The corporation in a democratic society: in whose interest ought it and will it be run? In Ansoff, H. (ed.), Business Strategy. Harmondsworth: Penguin Books, p. 225.

28. Hasan, Zubair (1983). "Theory of Profit: The Islamic Viewpoint", Journal of Research in Islamic Economics, 1 (1), pp. 1-16.

29. Holme, R. and P. Watts: 2000, 'Corporate Social Responsibility: Making Good Business Sense' (WBCS), http://www.wbcsd.org/newscenter/reports /2000/csr2000.pdf.

30. Ma, Weihua. (2005). Entrepreneurs' Mission in the Construction of Harmonious Society. [Online] http:// www.people.com.cn/ 4. 